Corrigendum

\title{
Corrigendum to "Radiocarbon dating, chronologic framework, and changes in accumulation rates of Holocene estuarine sediments from Chesapeake Bay" [Quaternary Research 57 (2002) 58-70]
}

\author{
Steven M. Colman, ${ }^{\mathrm{a}, *}$ Pattie C. Baucom, ${ }^{\mathrm{a}}$ John F. Bratton, ${ }^{\mathrm{a}}$ Thomas M. Cronin, ${ }^{\mathrm{b}}$ \\ John P. McGeehin, ${ }^{\mathrm{b}}$ Debra Willard, ${ }^{\mathrm{b}}$ Andrew R. Zimmerman, ${ }^{\mathrm{c}}$ and Peter R. Vogt ${ }^{\mathrm{d}}$ \\ ${ }^{\mathrm{a}}$ U.S. Geological Survey, 384 Woods Hole Road, Woods Hole, MA 02543, USA \\ ${ }^{\mathrm{b}}$ U.S. Geological Survey, National Center, Reston, VA 20192, USA \\ ${ }^{\mathrm{c}}$ Virginia Institute of Marine Science, Gloucester Point, VA 23062, USA \\ d Naval Research Laboratory, Code 7420, 4555 Overlook Avenue SW, Washington, DC 20375-5320, USA
}

Received 21 November 2003

Because of an error in the calculation of bulk densities from water contents, the cumulative masses in Fig. 8 are too high by a factor of about 2 . The actual correction depends to small degree on water content and ranges from 1.8 for a water content of $50 \%$ to 2.2 for a water content of $75 \%$. The values for mass accumulation rates in the left two columns of Table 5 are also affected, but the ratios between pre- and post-settlement times are not. A revised version of that table is given below. None of the major conclusions of the paper are materially affected.

Table 5

Comparison of pre- and post-1800 AD accumulation rates

\begin{tabular}{|c|c|c|c|c|c|c|}
\hline \multirow[t]{2}{*}{ Site } & \multicolumn{3}{|c|}{ Mass accumulation rate $\left(\mathrm{g} / \mathrm{cm}^{2} / \mathrm{yr}\right)$} & \multicolumn{3}{|c|}{ Sedimentation rate $(\mathrm{cm} / \mathrm{yr})$} \\
\hline & Post-1800 AD & Pre-1800 AD & $\begin{array}{l}\text { Ratio post/pre } \\
1800 \mathrm{AD}\end{array}$ & Post-1800 AD & Pre-1800 AD & $\begin{array}{l}\text { Ratio post/pre } \\
1800 \mathrm{AD}\end{array}$ \\
\hline 1 & 0.348 & 0.097 & 3.57 & 0.691 & 0.145 & 4.76 \\
\hline 2 & ND & ND & ND & ND & ND & ND \\
\hline 3 & 0.175 & 0.210 & 0.58 & 0.192 & 0.326 & 0.59 \\
\hline 4 & 0.175 & 0.103 & 0.21 & 0.050 & 0.219 & 0.23 \\
\hline 5 & 0.100 & 0.031 & 1.06 & 0.100 & 0.090 & 1.11 \\
\hline 6 & 1.429 & 0.340 & 4.20 & 1.786 & 0.277 & 6.45 \\
\hline
\end{tabular}

$\mathrm{ND}$, not determined.

\footnotetext{
is doi of original article 10.1006/S0033-5894(01)92285-9

* Corresponding author. Fax: +1-508-457-2310.

E-mail address: scolman@usgs.gov (S.M. Colman).
} 